\title{
Digital Strategies of Consumer Involvement and Innovation Dynamics: A Cross-Sector Explorative Study
}

\author{
Eleonora Paolocci ${ }^{1}$ \\ ${ }^{1}$ IULM University, Milan, Italy \\ Correspondence: Eleonora Paolocci, IULM University, Milan, Italy. E-mail: eleonora.paolocci@iulm.it
}

Received: May 24, 2014 Accepted: June 26, 2014 Online Published: September 28, 2014

doi:10.5539/ijms.v6n5p21 URL: http://dx.doi.org/10.5539/ijms.v6n5p21

\begin{abstract}
The study aims at exploring the collaborative dynamics between firms and consumers through Web tools. At present, there is limited empirical research aimed at investigating if and how the involvement of consumers in the implementation of open approaches, mediated by digital technologies, is actually implemented. The study presents a recent multifactorial investigation of the topic where literature lacks in. Through the Web-analysis of practices of a sample group of 180 companies operating in different market sectors, the author wants to explore spread and type profiles of collaborative strategies, investigating the existence of a possible correlation with the served markets and other moderator variables. Findings, identifying a 'spectrum' of engagement and co-creation mechanisms, suggest forms of aggregation and profiling in the approach followed by the firms and illustrate how the characteristics of virtual spaces allow them to explore new frontiers in the implementation of open approaches, with different degrees of involvement.
\end{abstract}

Keywords: co-creation, consumer insight, empirical research, open innovation (OI), virtual integration

\section{Introduction}

Existing academic literature suggests a significant potential of collaboration with consumers in the process of market value creation through ICTs (von Hippel, 2001; von Hippel \& Katz, 2002; Sawhney, Verona, \& Prandelli, 2005; Prandelli, Verona, \& Raccagni, 2006; Bilgram, Brem, \& Voigt, 2008; Füller \& von Hippel, 2008; Prandelli, Sawhney, \& Verona, 2008; Füller, Muhlbacher, Matzler, \& Jawecki, 2009; Morgan \& Wang, 2010). Considerable attention has been given to the benefits offered by the advent of digital technologies: low-cost interaction; increase in the speed and duration of the engagement process; easier sharing processes if compared to what can be done offline, where dynamics are limited to contexts of physical closeness (Dahan \& Hauser, 2002; Afuah, 2003). The importance of collaborating with consumers in the development of innovative products and services has been recognised for many years and there has been a steady proliferation of studies on this topic (von Hippel, 1976, 1978, 1986, 1988; Grönross, 1990; Day, 1991; Bruce, Leverick, Littler, \& Wilson, 1995; Gales \& Mansour-Cole, 1995; Prahalad \& Ramaswamy, 2004a; Vargo \& Lusch, 2004). However, it is only recently that the attention given to collaborative approaches, based on the emergence of a new creative consumer (Berthon, Pitt, McCarthy, \& Kates, 2007; Berthon, Campbell, Pitt, \& McCarthy, 2011; Jespersen, 2011; Page \& Pitt, 2011; Cova \& Cova, 2012), has grown exponentially. This area of research has been given new impetus especially by the rapid growth of the Web, a powerful platform to access external and distributed knowledge. Also, this new perspective is central in open-business innovation (Chesbrough, 2003, 2006, 2011) and in network-centric innovation (NCI) (Nambisan \& Sawhney, 2007) models. These approaches emphasise the need to continuously experiment around value creation and encourage companies to open up to new ideas coming from the outside, combining them with in-house ones.

However, the topic, from an empirical point of view, appears to be currently under-explored. There is still little work done to explore if and how consumer engagement processes, mediated by digital technologies, are actually implemented. In particular, while some studies are carried out within specific industries (e.g., Füller, Jawecki, \& Muhlbacher, 2007, on athletic footwear; Kim, Bae \& Kang, 2008, on MP3 players and mobile phone handsets in Korea; Garcia Martinez, 2013, on food products) literature lacks a cross-sector and multi-factorial investigation of the topic which relies on recent data and not limited to a specific geographic market. The topic deserves particular attention given the new opportunities that virtual environments offer: the challenge for firms is to transform new interaction opportunities into added value. Given the context illustrated and taking into due 
account the difficult application of the concept of strategic segmentation of the public to Web contexts (Hatch \& Schultz, 2010), the goal of this study is to understand if specific mechanisms have been put in place to enable Web-based collaboration with consumers. Specifically, the purposes are (1) investigating ways to kick off co-creation mechanisms, (2) empirical analysis of the following hypothesis: existence of typological profiles in the implementation processes of collaborative modalities; correlation between the identified profiles and the peculiarities of the served markets, along with other specific features of the companies in the sample group. To achieve this aim, explorative research has been carried out with a cluster analysis, aimed at identifying homogeneous groups of data. The study mainly adopts the point of view of the firm and the focus is on the engagement concept in its pragmatic interpretation (Gambetti \& Graffigna, 2010).

The structure of the paper is as follows: first, prior studies related to the phenomenon investigated will be reviewed; in the central section, methodology and findings will be illustrated. In the last section, results and managerial implications for marketing strategy will be discussed; the author also put forward suggestions for future research.

\section{Theoretical Background}

To address these overlooked issues, the present paper adopts a perspective that integrates different streams of literature related to: relationship marketing studies; new product innovation (NPI) research and collaborative marketing patterns; management and organisational studies on network-firm and Open Innovation (OI).

The concept of relationship marketing (Christopher, Payne, \& Ballantyne, 1991; McKenna, 1991; Pepper \& Rogers, 1993), and the research streams derived from it, apply the metaphor of personal relationship to the exchange processes between a company and consumers. A key idea, in the later development of this approach (Gummesson, 2002), is the potential that the Internet has to enhance the ability of firms to engage customers (Zineldin, 2000). NPI research has given great impetus to co-creation mechanisms (von Hippel, 1976, 1978, 1986, 1988; Grönross, 1990; Day, 1991; Webster, 1994; Gales \& Mansour-Cole, 1995; Bruce et al., 1995; Slater \& Narver, 1998; Verona, 1999; Krishnan \& Ulrich, 2001; Thomke, 1998, 2002; Danneels, 2002; Urban \& Hauser, 2002; Sawhney et al., 2005), identifying the power of collaboration, going beyond a company's borders and demand-pull dynamics as the main factors behind this process in current times. Literature on collaborative marketing (Prahalad \& Ramaswamy, 2004a; Vargo \& Lusch, 2004, 2006, 2008; Payne, Storbacka \& Frow, 2008) presents the concept of convergence between consumers and producers as an invitation to combine their respective skills in a partnership. The main focus is on the role of companies in identifying and supporting those consumers' activities which lead to value creation. The contribution of management studies on OI (Chesbrough, 2003, 2006, 2011; Nambisan \& Sawhney, 2007) and on the network and systemic model of organisations (Butera, 1995; Senge, Kleiner, Roberts, Ross, Roth, \& Smith, 1994; Gergen, Gergen, \& Barrett, 2004; Lane, Serra, Villani \& Ansaloni, 2006; Golinelli, 2010) is particularly relevant in connection to the idea of a collective enterprise. This is linked to the disappearance of organisational borders, the emergence of looser relationships and the enlargement of a company's network.

It is believed that only the combination of these separate theoretical bodies can yield the first insights to explore the complex nature of the investigated topic: each one takes on a different epistemological perspective, which highlights complementary aspects. Hence, our study is positioned at the intersection of these different research streams and, drawing on them, proposes a framework that identifies key dimensions that have to be taken into account to explore the investigated topic: relationship, engagement, value co-creation, openness.

\subsection{Transactional Model of Communication: A Relationship Based Pattern}

The Web changed the way consumers contact firms: the communication pattern is now based on multi-channel and multi-stakeholder communication and on a type of information transmission which can be defined as transactional (Duncan \& Moriarty, 1998), bi-directional and characterised by a continuous and dynamic exchange. The use of new interactive marketing tools and techniques has the purpose of fostering 'conversational relationships' with consumers (Stokes, 2000). What is new is the low-cost electronic management of the dialogue (Blattberg \& Deighton, 1991) and the fact that communication is not sequential (Stavrakantonakis, Gagiu, Toma, \& Fensel, 2013). Web tools have become a new component of corporate communication and allow organisations to establish strong relationships with their consumers (Mangold \& Faulds, 2009). Moreover, the potential of using social media as a tool to support the relationship has been highlighted by many authors (Granat, 2006; Kaplan \& Haenlein, 2009, 2010; Vasalou, Joinson, Bänziger, Goldie, $\&$ Pitt, 2008). In a systemic approach to the study of economic organisations, the emergence of a new model based on the management of relationships has been observed (Golinelli, 2010). In this model, firms focus more and more on the creation of a specific function with this specific task. This should allow them to benefit from 
existing external resources, skills and innovative knowledge. Another area of organizational studies which has identified interesting concepts is that of generative dialogue: a co-created dialogue, taking new perspectives into account (Palmer, Benveniste, \& Dunford, 2007) and generating ideas and alternatives. A field of research analyses innovation processes through the lens of generative dialogue and maintains that the knowledge networks stimulate innovation through "generative relationships" (Lane \& Maxfield, 2005; Lane et al., 2006) between heterogeneous subjects developing constructive interactions, outside the exchanges which are traditionally linked to economic transactions. These changes can in turn lead to new products, processes or services.

\subsection{Consumer Engagement as a Dynamic, Collaborative and Interactive Process}

While the traditional perspective on consumer engagement considered value creation as a firm-centric activity, with little emphasis on interactive dialogue and where companies had a limited understanding of consumer knowledge developed within their specific contexts of experience, as previously observed by Sawhney et al. (2005), recent studies reveal the complex multidimensional and dynamic nature of consumer engagement, which comprises of a range of sub-processes reflecting consumers' interactive and value co-creation experiences (Brodie, Hollebeek, Jurlic, \& Ilic, 2011). Indeed, the main dimensions associated with engagement in the marketing literature are: involvement (Sawhney et al., 2005), empowerment (Shaw, Newholm, \& Dickinson, 2006), interaction (Ahuja \& Medury, 2010), activation, including the interaction, participation, collaboration and co-creation components (Hoeffler \& Keller, 2002; Etgar, 2008). In the literature on NPD, the concept of engagement has been analysed mainly from the perspective of empowerment and of its links with perceived customer orientation, purchase intentions, and customers' attitudes towards the company (Fuchs \& Schreier, 2011). More specifically, as for the first point, the concept has been explored through two key aspects: 1 . consumer empowerment to create and generate ideas for new product designs (empowerment to create); 2. consumer empowerment to select and "vote" which product designs should be produced and sold (empowerment to select). Web tools facilitate new and extended forms of interactive consumer experiences, which may contribute to the development of engagement with companies and brands. In particular, interactive relationships in the virtual world reflect Vivek, Beatty and Morgan (2012) expanded relationship marketing domain, and Vargo's (2009) transcending view of relationships, which provide a conceptual foundation for the consumer engagement concept, defined as "the intensity of an individual's connection with an organization's offerings and/or organizational activities, which either the customer or the organization initiate" (Vivek et al., 2012, p. 4). According to this perspective, the development of any strategy focusing on consumer engagement will need to find a place for consumers to have their voice heard (Perks \& Sedley, 2008).

\subsection{Consumers as Market Partners and Co-Creators of the Offer}

Literature indicates that companies are using customisation and collaborative processes with consumers to grasp product ideas and reduce development risk (Greer \& Lei, 2012). In the mid-2000s collaborative marketing approaches emerged (Prahalad \& Ramaswamy, 2004a, 2004b, 2004c; Payne et al., 2008), spurred also by the new so-called Service Dominant Logic (Vargo \& Lusch, 2004, 2006, 2008), whereby marketing is not just directed at consumers, but is developed with consumers. This perspective is based on the key concept according to which value is co-created in the interaction between companies and consumers (Ramirez, 1999; Prahalad \& Ramaswamy, 2004a, b) and on the figure of consumers as market partners who own resources. Collaborative marketing has its roots in the research on services marketing (Grönross, 1990), where co-production is at the basis of the service system and in the studies on product innovation and design, which look at users as potential collaborators of companies (von Hippel, 1986; Thomke \& von Hippel, 2002). In the context of this last field, studies on lead users have particular relevance. This approach focuses on the creative role of a specific category of consumers, defined by von Hippel $(1978,1986,1988,2001)$ as expert users, at the forefront of a specific field, who are at the origin of new concepts and solutions. Often they are even more knowledgeable than companies' experts, they are interested and motivated to promote a product sector's evolution, so that it can meet their expectations in a more and more adequate way. Von Hippel's suggestion highlights how companies have gradually moved from a technical-production approach to an approach which is linked to the active involvement of customers. This is defined Consumer Active Paradigm. Digital environments offer many opportunities to support the direct involvement and to integrate and value consumers' contributions. The Web, using Afuah's words (2003), makes it easier to access skills, electronic archives and communities where knowledge is already codified and digitalised, ready to be recombined. Wind and Rangaswamy (2001) have coined the term customerisation to define a new approach which companies can follow to combine high levels of technological differentiation and customisation of the end product, made possible by modular platforms, with high levels of marketing differentiation, thus offering highly analytical and targeted informative content. 


\subsection{A Paradigm Shift toward External Innovation Processes}

There is increasing consensus among academics and practitioners on the paradigm shift from internal innovation to open innovation processes (Keinz, Hienerth \& Lettl, 2012). Focus is placed on the limitations of traditional production-based innovation processes in order to overcome the commodity trap. This is linked to the fact that products quickly lose their attractiveness for end consumers and that, over time, a company's product becomes indistinguishable from others available on the market (Chesbrough, 2003, 2006, 2011). Open Innovation is defined as the antithesis of a vertical integration model, as it integrates internal and external flows of knowledge with the aim of accelerating a company's innovation process and expand markets through third-party channels. This generates a positive cross-pollination between heterogeneous knowledge. The direct involvement of consumers in innovation processes, which promotes the sharing of tacit knowledge (Nonaka, 1991; Nonaka \& Takeuchi, 1997) with companies, helps solving difficulties arising from knowledge which cannot be transferred with technical-scientific language, but which is based on the sharing of practices and interaction. In an open model it is more difficult for competitors replicate concepts, solutions and the value proposition as they are based mainly on the sharing of non-codified knowledge between partners. Also, consumers are less inclined to leave the company. The joint work by Nambisan and Sawhney (2007) which introduces the concept of network-centric innovation (NCI) and the need to continuously experiment around value creation, follows the same approach. NCI is defined as an externally focused approach to innovation that relies on harnessing the resources of external networks and communities to amplify innovation reach / speed and the quality of outcomes. With the creation of virtual environments to manage relationships with consumers, firms can foster their systematic engagement (Swink, 2006; Nambisan 2003).

\section{Propositions and Research Questions}

Based on the insights from the reviewed literature, the following proposition has been formulated:

P1. Different approaches related to the OI paradigm can be adopted by firms: a 'spectrum' of potential forms of collaboration, at different product life-cycle stages, market levels, with heterogeneous objectives and degrees of consumer involvement.

Although there is considerable literature demonstrating the benefits and potential of digital consumer involvement, empirical support about the implementation approaches followed by firms appears to be scarce. Hence, the following set of research questions have been considered as critical to define the relevance of the investigated topic and will drive the study:

RQ1. Which specific mechanisms have been put in place to enable Web-based engagement and collaborative processes with existing or potential consumers and how widespread is their use?

RQ2. Is it possible to identify different typological profiles in their implementation? If so, does a correlation exist between the identified profiles and the peculiarities of the served markets, the specific industries and with other features of the companies?

\section{Study design}

\subsection{Scope of the Investigation}

The universe of reference is the company. The scope of the investigation is circumscribed to the analysis of the dynamics related to Web-based collaborative processes of physical consumption goods. It focuses on business to consumer markets (B2C), given some prerogatives which make their exploration particularly stimulating. First, Web-based co-creation processes are the most advanced developments in terms of sharing customer knowledge with a company. Second, the extension of the principles of open source movements to non-immaterial goods, is supported by the idea that every product is also a concept and an information product, especially at development stage. Third, studies on collaborative processes were originally carried out mainly on B2B markets, where they can boast a longer tradition (e.g., concept of customer-supplier interaction, largely explored since the 80s by the researchers of the IMP - Industrial Marketing and Purchasing; social media utilization in B2B relationships: Kärkkäinen, Jussila \& Väisänen, 2013). Fourth, B2C markets are characterised by more elements of risk, due to the size of the scope of reference and the wider language gap linked to the difficulty of directly understanding needs. Coherently, the methodological choice for the analyzed industries excludes companies which exclusively operate in B2B markets, offer immaterial goods as their core business and that only deal in distribution activities. However, in constructing the theoretical background, the author also referred to concepts taken from models which originate in the B2B and service markets, as they are useful to have an holistic understanding of the studied phenomenon. 


\subsection{Sample}

This explorative study was carried out following a quantitative methodology and a sample of companies belonging to nine different sectors of physical consumption goods. To select the product industries, the following reports (Note 1) were jointly analyzed and considered. Different factors were taken into account, such as fastest growers, most profitable, most bang for buck, brand reputation and other critical features: Fortune World's Most Admired Company; Brand Finance Best Global Brands; Fortune Global 500 - Annual ranking of the world's top industries. In order to select the units, the method of judgmental or purposive sampling (Lavrakas, 2008, p. 646) was chosen. The method is generally used to study phenomena which can theoretically exist in a wide population, but in practice are expected to be concentrated in some specific areas. For example, the choice was made to exclude micro and small manufacturing companies as, based on a first explorative analysis, their absence from virtual environments was observed, or at least a scattered digital presence which could not enable an effective analysis of codified typologies. The final sample, from the Bureau Van Dijk Electronic Publishing Directory (Note 2), consists of 180 companies (see Appendix 1 for the complete list), 20 for each of the following sectors: Apparel, sportswear, shoes and accessories; Automotive; Consumer packaged goods (CPG): household, family and personal care, beauty; Consumer electronics and appliances; Consumer packaged goods (CPG): food industry; Furniture and accessories; Pharmaceutical and healthcare; Toys, videogames, hobby modelling; Stationery, adhesives, hobby paint products.

\subsection{Methodology and Data Collection}

The method used envisages the Web-analysis of practices of the firms belonging to the sample-group. Adopting the technology-in-practice approach suggested by Orlikowski (2000) and moving from the theories by Korkman, Storbacka and Harald (2010), the goal is the description of the ways in which collaborative dynamics can develop starting from practical engagement. This involves a mapping activity in the virtual environment, aimed at exploring if and how companies consider the adoption of Web tools to connect to consumers and cooperate with them with different degrees of involvement, until the highest level of collaborative innovation, following the integrated marketing and innovation management perspective suggested by Stephen and Toubia (2010). The survey unit is represented by the open virtual spaces, which may be observed by any external subject. A similar method was used by Prandelli et al. (2006); Alexy, Criscuolo \& Salter (2012); Russo-Spena \& Mele (2012). The data collection occurred in Winter 2013-2014. In order to operationalise the variable "Type of mechanisms put in place by the firm to enable collaborative processes", an explorative analysis was carried out to identify its possible ways - Coding of practices -. To this purpose, the method of content analysis (Krippendorff, 1980) was used, following the steps recommended by Kassarjian (1977). The process of analysis let to the identification of the following categories, characterised by different degrees of consumer involvement:

\section{- Technology-driven channels to collect ideas (Note 3)}

Primary target: scientific and business community - B2B partnering, inventors, researchers -. Accepted contribution types: mainly breakthrough or radical innovation oriented - new products, ingredients, technologies, materials, packaging and process innovations, in some cases already patented -. Communication modality: one-to-one - forms; e-mails - and one-to-many. Types of channels: collaborative platforms, portals or dedicated pages within the corporate website.

Potentially, this first category may involve, as secondary targets, expert consumers / lead-users as theorised by Hippel and creative consumers, as identified by Berthon et al. (2007), given that «users may possess knowledge in the application domain and knowledge in the technology domain of the product» (Jespersen, 2011, p. 1145; see also: Magnusson, 2009; Fuchs \& Schreier, 2011).

\section{- Market oriented channels to collect ideas, understand the user experience and catch consumer insights}

Target: mass open approach - cross-target - (Note 4). Type of accepted contributions: any, not limited to breakthrough innovation - also incremental innovation oriented -, but aimed to the activation of market competencies and skills and to facilitate a 'consumer self-revelation' and 'customer self-disclosure' process (Andrade, Kaltcheva, Weitz, 2002; Zwass, 2010), such as: «a new concept», «ideas for advertising/promotions», «new suggestions for brands», «sustainability ideas», «product enhancements», «marketing plans or new product names». Communication modality: one-to-one - forms; e-mails - and one-to-many. Types of channels: collaborative platforms, platforms or dedicated pages within the corporate website.

\section{- Idea Communities (Note 5)}

Communication modality: one-to-many and many-to-many. Target: mass open approach - cross-target -. Type of accepted contributions: any, not limited to breakthrough innovation, but aimed to the activation of market 
competences and skills - also incremental innovation oriented -. Types of channels: open collaborative platforms.

Danneels's contribution (2002) on the implications of strategic alternatives to innovation further explores the first three typologies, highlighting the role of consumers among the possible actors which may be involved by crossing the options related to the knowledge needed to develop innovation - with more technological or market significance - and the subjects to be involved in each case - technology oriented partners in the first case, customers with innovation relevant knowledge in the other-.

- $\quad$ On-line contests:

- aimed to trigger competitive mechanisms on ideas: design competitions, collaborative advertising initiatives, also in partnership with external platforms, creative communities and social networks;

- $\quad$ aimed to collect consumer insights (Note 6) and better understand the user experience.

- Web business games / online idea competitions (Note 7) which involve international students: they have communication and strategic purposes of employer branding, but also of input collection and innovation management. The target is usually represented by university/design school students and, more generally, "young talents".

Literature has addressed motivation for consumers, and several incentives and stimulators to encourage participation have been identified (Etgar, 2008; Kaiser \& Muller-Seitz, 2008; Ojanen \& Hallikas, 2009; Füller, 2010; Nambisan \& Baron, 2007, 2009). Consistent with the theoretical background, for both these two last types of modalities, the data collection has identified the presence of any Economic rewards and/or Social value incentives to collaborate - fun, exposure, psychological reasons, career perspectives and so on -.

- Online product customisation (Note 8): possibility to customise and personalise the aesthetic and functional attributes through configuration tools.

- Online consumer surveys with open and spontaneous participation, publicised on the corporate sites / brand sites / official pages of social networks.

- Activation of a general "Suggestions" channel, usually through tools such as a suggestions box, or a specific item in the drop-down menu in the Contact area.

- Activation of a "Feedback / Consumer experience" channel, specifically related to products: this is not simply referred to "complaints or general comments about services or company". It usually is a dedicated page, a tailor-made section in the web product pages, or a specific item in the drop-down menu in the Contact area. Romero and Molina (2011) define innovation processes based on this type of channel Existing Product Adaptation. The same approach is followed by Boztepe (2005), according to whom successful organization are those which can quickly adapt different versions of their products based on real-time feedback from consumers.

- Explicit regulation "Unsolicited ideas submission" / "External proposals policy", usually in the sections: Legal notice, Disclaimer, Terms and conditions, Contact us, FAQ.

- Explicit exclusion of online modality to collect ideas, suggestions and external contributions, with indication of off-line channels to communicate with the firm and kick off a bi-directional interaction.

To further investigate in a deeper way the strategies adopted by firms, the empirical observation has been crossed with other moderator variables in addition to the product sector (Note 9): Firm's headquarters (North America and Canada; Central and South America; Western Europe; Eastern Europe; Asia; Oceania; Africa); Firm's age; Firm's size; Type of business (only B2C; B2C+B2B); Presence of a Corporate Social Responsibility (CSR) / Sustainability policy; Presence of specific references to the expression "Stakeholder engagement" in the official documents available on the Web and related to the CSR policy (e.g.: CSR Report); eCommerce strategy (eCatalogue; online shopping cart; other shopping tools - e.g.: "request a quote; apply for credit; online retailers direct link" -; social integration with social media and / or review and advice system); Presence of specific references of the following terms in the firm's Mission \& Vision, Annual Reports and other official documentation available online: Openness; Innovation; Open Innovation (OI); Listening to the consumers; Variables related to the firm's digital engagement strategy, particularly the active and official presence on social media (Facebook page; Linkedin profile; Youtube channel; Twitter profiles; Official blogs / forums). 


\section{Data Analysis and Findings}

\subsection{Descriptive Analysis}

A preliminary frequency analysis on empirical data has been performed for the purpose of observing and characterizing the amount and general distribution of the investigated phenomenon (Figure 1) before it can be explained with more analytical methods. First results highlight that the most used collaborative mechanism by the firms in the sample-group is that of "Online creative and ideas contests" (52.8\%). The majority of firms that have launched "Online creative contests to collect ideas" (66.3\%) or "Online contests to collect consumer experience insights" (82.3\%), have only used economic incentives to encourage participation, while both types of incentives, social and economic rewards, have been used by the majority of firms (39\%) that have launched "Web business games". The majority of companies that have implemented technology-driven channels have opted for a more evolved model, a tailor-made collaborative and co-creation platform or a dedicated micro-site within the corporate official site $(51.2 \%)$; only one firm (2.3\%) has implemented both channel types, while $46.5 \%$ has opted for a more traditional channel (form or e-mail, dedicated page in the official corporate site, usually in the Innovation section); in the majority of cases external links to social networks are also absent $(62.8 \%)$. The majority of companies that have implemented market oriented channels have opted for a traditional approach where consumers can submit new product ideas and insights (89.5\%), only $10.5 \%$ have implemented a more evolved model; external links to social networks are also usually absent $(60.5 \%)$. With reference to the Idea Communities model, in the majority of cases (85\%) these are proprietary platforms - the firm can boast exclusive rights on its followers -, present external links to social media $(60 \%)$ and a mechanism of review/voting system or an idea testing system (90\%). Only $15 \%$ has opted for an external partnership and a mixed-type approach (e.g. specialised co-creation platforms). The absolute majority (99.4\%) of the firms has implemented at least one of the coded engagement and collaborative mechanisms. Only one firm has implemented no mechanism; nevertheless, it is characterised by a basic connecting strategy - presence on social media -.

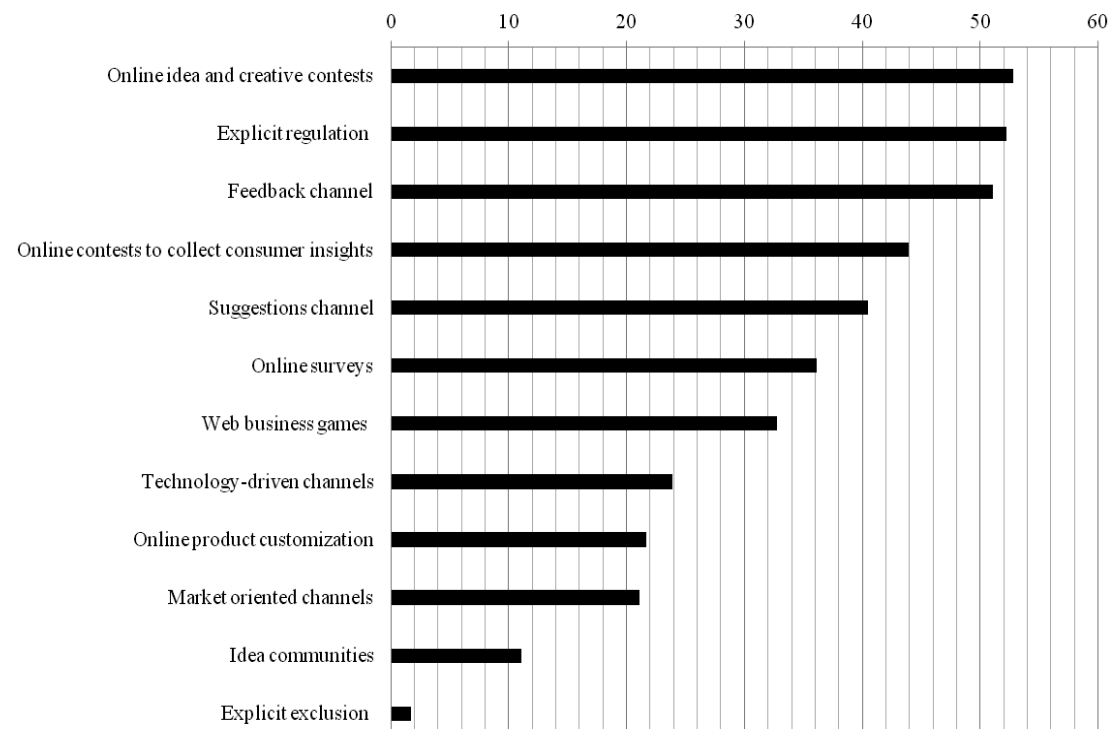

Figure 1. Hierarchy of collaborative and engagement strategies recorded

\subsection{Cluster Analysis}

A multivariate, statistical analysis has been carried out on the empirical material to identify homogeneous groups of data. As all variables are categorical, dichotomous or ordinal - size and age of the company -, the TwoStep method has been used. Its peculiarity lies in the fact it can handle even qualitative variables by extending the model-based distance measure used by Banfield and Raftery (1993). To summarise, the analysis carried out through this method has pointed out the findings described below.

1) By subdividing all companies into two clusters it is possible to obtain the best classification based on the scores for the 52 variables taken into account; 
2) Table 'Clusters' (Table 1) shows that the largest cluster (cluster 2) includes $52.8 \%(\mathrm{~N}=95)$ of the analyzed companies, while the other one (cluster 1 ) includes the remaining $47.2 \%(\mathrm{~N}=85)$.

Figures 2 and 3 show the bar charts of the only two ordinal variables, that is size and age of the company. As for the first chart, we can see that the darker area (which represents cluster 1) is larger than the lighter one (which represents cluster 2) in area 4, which indicates multinational companies. No company in cluster 1 has a medium size (value 1), as the value 1 bar has no dark portion. As for the second chart, no company in cluster 1 is a start-up; a small percentage, in comparison to companies in cluster 2, is young or middle-aged; mature companies are evenly distributed in the two clusters, while companies older than 100 year mainly belong to cluster 1 .

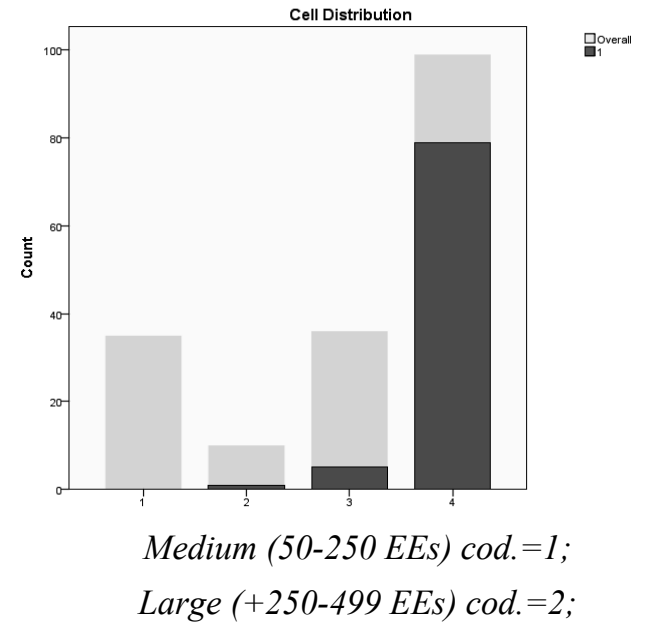

Very large domestic $(+500)$ cod. $=3$;

Multinational ( +500 , operations and facilities in more than one country) cod. $=4$

Figure 2. Firm's size

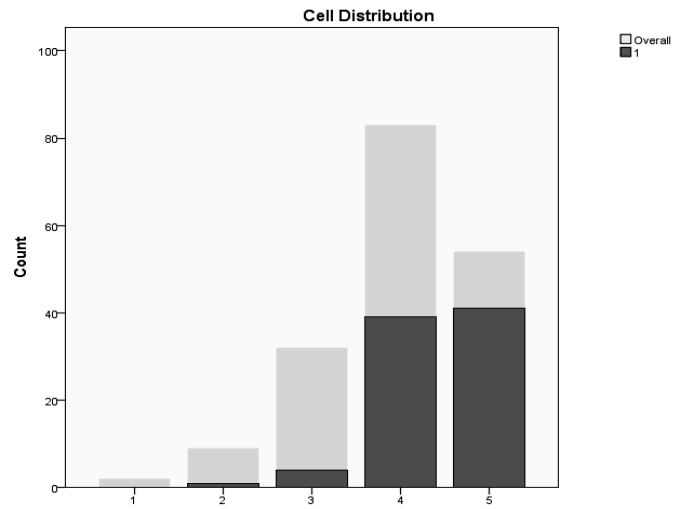

Start-up (younger than 2 years) cod. $=1$;

Young (+2-10) cod. $=2$;

Middle-aged $(+10-25)$ cod $=3$;

Mature (+25-100) cod $=4$;

Old $(+100)$ cod $=5$

Figure 3. Firm's age

Companies in cluster 2 (larger than cluster 1) show a strategic behaviour which may be defined as more conservative and traditional than that of cluster 1 companies, which follow a more evolved behaviour.

An analytical reading of the analyzed variables, listed in decreasing order in terms of the discriminating power they had in defining two cohesive clusters, shows that the variable where the two clusters show the greatest difference is: 'Presence of specific references to: 'Stakeholder engagement' in the online official documentation related to the CSR policy. In cluster 2 the mode corresponds to answer 0 (91.6\%), while in cluster 1 mode is answer $1(94.1 \%)$. Besides, firms in cluster 1 are characterised, to a greater extent, by the presence of a CSR policy $(98.8 \%)$ in comparison to cluster $2(55.8 \%)$. The other relevant factors are represented by:

- $\quad$ size of the company: in cluster 2 mode is 1 (medium size), and the occurrence percentage is $36.8 \%$, while in cluster 1 mode is 4 (multinational) in $92.9 \%$ of cases;

- presence of the expressions "Listening to the consumers": in cluster 2 mode is 0 (absent), and the occurrence percentage is $90 \%$, while in cluster 1 mode is 1 (present), with $68.2 \%$ of cases;

- digital presence, with particular reference to Youtube channel - in cluster 2 mode is 0 (absent), and the occurrence percentage is $60 \%$, while in cluster 1 mode is 1 (present), in $96.5 \%$ of cases - and to the activation of "Official blogs and forums" - in cluster 2 mode is 0 (absent), and the occurrence percentage is $76.8 \%$, while in cluster 1 mode is 1 (present), in $60 \%$ of cases -;

- type of business: in cluster 2 mode is B2C, and the occurrence percentage is $77.9 \%$, while in cluster 1 mode is $\mathrm{B} 2 \mathrm{C}+\mathrm{B} 2 \mathrm{~B}$, with $81.2 \%$;

- "Online idea and creative contests" with economic rewards: in cluster 2 mode is 0 (absent), and the occurrence percentage is $78.9 \%$, while in cluster 1 mode is 1 (present), in $77.6 \%$ of cases; 
- $\quad$ specific references to the term "Open Innovation": in both clusters mode is 0 (absent), but the occurrence percentage is $98.9 \%$ in cluster 2 against $51.8 \%$ in cluster 1 .

The variables on the following rows can be interpreted in the same way. It is worth noticing, in particular, the features of the following variables in the two clusters:

- "Explicit regulations": in cluster 2 mode is 0 (absent), and the occurrence percentage is $71.6 \%$, while in cluster 1 mode is 1 (present), in $78.8 \%$ of cases;

- "Online consumer surveys": in cluster 2 mode is 0 (absent), and the occurrence percentage is $84.2 \%$, while in cluster 1 mode is 1 (present), in $58.8 \%$ of cases;

- " "Online contest to collect consumer insights" with economic rewards: in cluster 2 mode is 0 (absent), and the occurrence percentage is $75.8 \%$, while in cluster 1 mode is 1 (present), in $61.2 \%$ of cases;

"Feedback/Customer experience channel": in cluster 2 mode is 0 (absent), and the occurrence percentage is $58.9 \%$, while in cluster 1 mode is 1 (present), in $62.4 \%$ of cases;

- $\quad$ eCommerce strategy, presence of a social integration: in cluster 2 mode is 0 (absent), and the occurrence percentage is $53.7 \%$, while in cluster 1 mode is 1 (present), in $56.5 \%$ of cases.

The comparison between the two cells of each row suggests that companies in cluster 1 are the most inclined to the use of digital tools to establish a connection with consumers. In particular, they use the considered engagement and collaborative mechanisms. They are larger in size, older, and work in both B2C and B2B markets $(81.2 \%$, compared to only $22.1 \%$ of companies in cluster 2$)$. Outcomes do not confirm the hypothesis of a possible socio-geographical pattern linked to the headquarters location, West vs emerging countries. Results almost show a "globalised" view of strategic approaches related to the investigated topic. However, this should be statistically interpreted taking into account the fact that companies which operate in emerging countries, are under-represented in the studied sample. Asian companies, on the other hand, cannot be considered as typical of cluster 1 or cluster 2 as they are evenly distributed.

In terms of sectors where companies operate, the analysis suggests that this variable is not one of the main discriminating criteria, but present a "typological" behaviour anyway, confirming what had emerged from the preliminary descriptive analysis:

- companies in the Consumer electronics and appliances; Automotive; CPG - Beauty, household, family / personal care; Healthcare / Pharmaceutical; $C P G-$ Foods sectors are mainly included in cluster 1;

- companies operating in the Toys, video games, hobby modelling; Furniture and accessories; Stationery, adhesives, hobby paints products; Apparel, sportswear, shoes and accessories sectors are mainly included in cluster 2.

It is also important to notice how companies belonging to cluster 1 - in contrast to companies in cluster 2 - also show a higher number of occurrences for the following variables, in this order: activation of a Linkedin profile, Online students competitions with economic rewards, activation of a Twitter profile, presence of the term "Innovation", Online students competitions with social rewards, presence of the term "Openness", implementation of evolved Technology-driven channels, Idea communities (with presence of an idea testing / voting system), Idea Communities (proprietary type), implementation of traditional Technology-driven channels, Idea Communities (with the presence of social links), Other shopping tools with reference to the eCommerce strategy, Online product customisation, activation of a Facebook profile, Online idea and creative contests with social rewards, implementation of evolved Market oriented channels, Online contests to collect consumer insights with social rewards, Idea communities (external ownership / partnership). Correspondingly, it is interesting to see that companies belonging to cluster 2 show a higher number of occurrences for the following variables, in this order: traditional Market oriented channels, Suggestions channel, Explicit exclusion, Online shopping charts (direct shopping) and eCatalogues related to the eCommerce strategy. 
Table 1. Clusters

\begin{tabular}{|c|c|c|c|}
\hline \multirow{2}{*}{$\begin{array}{l}\text { Cluster } \\
\text { Size }\end{array}$} & \multirow{2}{*}{ Hierarchy } & \multirow{2}{*}{$\begin{array}{c}2 \\
52.8 \%(95)\end{array}$} & 1 \\
\hline & & & $47.2 \%(85)$ \\
\hline \multirow{49}{*}{ 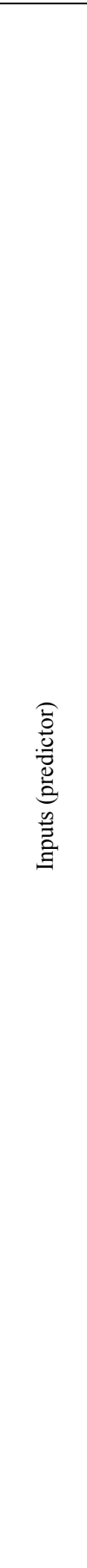 } & 1. & "Stakeholder engagement / dialogue": 0 (91.6\%) & "Stakeholder engagement / dialogue": 1 (94.1\%) \\
\hline & 2. & Firm's size: $1(36.8 \%)$ & Firm's size: $4(92.9 \%)$ \\
\hline & 3. & "Listening to the consumers": $0(90.5 \%)$ & "Listening to the consumers": $1(68.2 \%)$ \\
\hline & 4. & Digital presence - Youtube channel: $0(60 \%)$ & Digital presence - Youtube channel: $1(96.5 \%)$ \\
\hline & 5. & Type of business - Only B2C=cod. 1: $1(77.9 \%)$ & Type of business - B2C + B2B=cod.2: $2(81.2 \%)$ \\
\hline & 6. & Online idea contests (economic rewards): $0(78.9 \%)$ & Online idea contests (economic rewards): 1 (77.6\%) \\
\hline & 7. & "Open Innovation": $0(98.9 \%)$ & "Open Innovation": $0(51.8 \%)$ \\
\hline & 8. & Digital presence - Linkedin profile: $1(50.5 \%)$ & Digital presence - Linkedin profile: $1(97.6 \%)$ \\
\hline & 9. & Presence of a CSR policy: $1(55.8 \%)$ & Presence of a CSR policy: $1(98.8 \%)$ \\
\hline & 10. & Explicit regulation: $0(71.6 \%)$ & Explicit regulation: $1(78.8 \%)$ \\
\hline & 11. & Student competitions (economic rewards): $0(95.8 \%)$ & Student competitions (economic rewards): $0(52.9 \%)$ \\
\hline & 12. & Digital presence - Twitter profile: $1(61.1 \%)$ & Digital presence - Twitter profile: $1(100 \%)$ \\
\hline & 13. & Presence of references to "Innovation": 1 (64.2\%) & Presence of references to "Innovation": $1(100 \%)$ \\
\hline & 14. & Online consumer surveys: $0(84.2 \%)$ & Online consumer surveys: $1(58.8 \%)$ \\
\hline & 16. & "Openness": $0(89.5 \%)$ & "Openness": $0(51.8 \%)$ \\
\hline & 17. & Firms' age: $4(46.3 \%)$ & Firms' age: $5(48.2 \%)$ \\
\hline & 18. & Technology-driven channels: evolved type: $0(100 \%)$ & Technology-driven channels: evolved type: 0 (72.9\%) \\
\hline & 19. & Digital presence - Official blogs / forums: $0(76.8 \%)$ & Digital presence - Official blogs / forums: $1(60 \%)$ \\
\hline & 20. & Consumer insight contests (economic): $0(75.8 \%)$ & Consumer insight contest (economic): $1(61.2 \%)$ \\
\hline & 21. & Idea Communities (ideas testing / voting): $0(100 \%)$ & Idea Communities (ideas testing / voting): $0(78.8 \%)$ \\
\hline & 22. & Idea Communities (owned platform type): $0(100 \%)$ & Idea Communities (owned platform type): $0(80 \%)$ \\
\hline & 23. & Consumer electronics. appliances: 0 (97.9\%) & Consumer electronics. appliances: $0(78.8 \%)$ \\
\hline & 24. & Traditional technology-driven channels: 0 (96.8\%) & Traditional technology-driven channels: $0(78.8 \%)$ \\
\hline & 25. & Idea communities (presence of social links): $0(98.9 \%)$ & Idea communities (presence of social links): $0(83.5 \%)$ \\
\hline & 26. & eCommerce strategy - Other shopping tools: $0(91.6 \%)$ & eCommerce strategy - Other shopping tools: $0(70.6 \%)$ \\
\hline & 27. & Online product customisation : $0(87.4 \%)$ & Online product customisation: $0(68.2 \%)$ \\
\hline & 28. & Digital presence - Facebook: $1(84.2 \%)$ & Digital presence - Facebook: $1(97.6 \%)$ \\
\hline & 29. & Toys. video games. hobby modelling: 0 (82.1\%) & Toys. video games. hobby modelling: $0(96.5 \%)$ \\
\hline & 30. & "Feedback/Customer experience" channel: 0 (58.9\%) & "Feedback/Customer experience" channel: 1 (62.4\%) \\
\hline & 33. & Furniture and accessories: $0(82.1 \%)$ & Furniture and accessories : $0(92.9 \%)$ \\
\hline & 34. & Stationery. adhesives. hobby paint products: $0(82.1 \%)$ & Stationery. adhesives. hobby paint products: $0(92.9 \%)$ \\
\hline & 35. & Market oriented channels - evolved model: $0(100 \%)$ & Market oriented channels - evolved model: $0(95.3 \%)$ \\
\hline & 36. & Apparel. sportswear. shoes and accessories: 0 (84.2\%) & Apparel. sportswear. shoes and accessories: 0 (94.1\%) \\
\hline & 37. & Beauty. household. family / personal care: $0(90.5 \%)$ & Beauty. household. family / personal care: $0(80.0 \%)$ \\
\hline & 38. & Market oriented channels: traditional model: $0(75.8 \%)$ & Market oriented channels: traditional model: $0(87.1 \%)$ \\
\hline & 39. & Consumer insight contests (social rewards): $0(95.8 \%)$ & Consumer insight contests (social rewards): $0(88.2 \%)$ \\
\hline & 40. & "Suggestions" channel: $0(53.7 \%)$ & "Suggestions" channel: $0(65.9 \%)$ \\
\hline & 41. & HQ Eastern Europe: 0 (96.8\%) & HQ Eastern Europe: $0(100 \%)$ \\
\hline & 42. & HQ Oceania: $0(96.8 \%)$ & HQ Oceania: $0(100 \%)$ \\
\hline & 43. & Healthcare / Pharma: $0(91.6 \%)$ & Healthcare / Pharma: $0(84.7 \%)$ \\
\hline & 44. & eCommerce strategy: Social integration: $0(53.7 \%)$ & eCommerce strategy: Social integration: 1 (56.5\%) \\
\hline & 45. & HQ Asia: $0(85.3 \%)$ & HQ Asia: $0(80 \%)$ \\
\hline & 46. & HQ North America and Canada: 0 (65.3\%) & HQ North America and Canada: 0 (58.8\%) \\
\hline & 47. & HQ Western Europe: 0 (55.8\%) & HQ Western Europe: $0(61.2 \%)$ \\
\hline & 48. & Idea communities (external/partnership): 0 (98.9\%) & Idea communities (external / partnership): $0(97.6 \%)$ \\
\hline & 49. & Explicit exclusion of online modalities ...: $0(97.9 \%)$ & Explicit exclusion of online modalities ...: $0(98.8 \%)$ \\
\hline & 50. & eCommerce strategy: Online shopping carts: 0 (55.8\%) & eCommerce strategy: Online shopping carts: $0(57.6 \%)$ \\
\hline & 51. & eCommerce strategy: eCatalogue: 1 (95.8\%) & eCommerce strategy: eCatalogue: $1(95.3 \%)$ \\
\hline & 52. & CPG - Food: $0(87.4 \%)$ & CPG - Food: $0(87.1 \%)$ \\
\hline
\end{tabular}

\section{Conclusion}

\subsection{Discussion}

The analysis shows that the rapid advances in ICTs are encouraging the spread of digital and media technology and their use by firms to engage consumers and foster relationships: connecting with consumers through digital tools emerges as an "institutionalised" practice, a general cross convergence in managerial behaviour.

As for the study proposition (P1), the study confirms that different open approaches mediated by Web tools can be adopted by firms. These approaches create a 'spectrum' of ways to absorb external knowledge, with different 
impacts on the content and process of knowledge, which imply heterogeneous goals and different degrees of consumer involvement.

More specifically, for the first research question (RQ1), the process of content analysis enabled the identification of heterogeneous categories characterised by different degrees of consumer involvement. This confirms the assumption of a previous work by Jespersen (2011), according to whom "Online channels do not necessarily empower users in the innovation process" (ivi, p. 1141).

In general, the study reveals a strong managerial focus on the launch of temporary initiatives, mainly centred on individual brands and often targeted at specific geographical markets, as a way of experimenting. These initiatives are characterised by a tactical nature, short-term goals and mainly brand engagement and word of mouth goals. Emerged data indicate how companies are taking the first steps in this new territory. Actual Open Innovation, if and where implemented, is mainly carried out through one-to-one relationships. Finally, the study shows that companies have not yet turned their attention to long-term engagement and collaborative modalities and strategic vision. Nevertheless, the research has been possible to detect and isolate useful emerging trends and new approaches, whose development stage is expected to be very interesting: as today's competitive environment demands, these modalities go beyond merely importing the "voice of the consumer" through traditional offline market research mechanisms.

With reference to the second (R2) research question previously stated in the paper, findings from the cluster analysis carried out, indicate that different typologies in the implementation strategies of Web-based engagement and collaboration with consumers exist. Factors such as the sector where a company operates, the presence of a policy related to CSR, the size and the age of the company, the type of business, its eCommerce strategy and the variables related to the firm's digital active and official presence on social media, appear to be significant and suggest new forms of aggregation and profiling in the approach followed by the company referred to open approaches and collaborative mechanism: from a more conservative and closed approach, to a mass open and market driven strategy. If we take a closer look at the identified correlations, the most conservative companies, which are less inclined to the adoption of collaborative policies, operate in the in Furniture and accessories; Apparel, sportswear, shoes and accessories and Toys, video games, hobby modelling industries. These are mature sectors, traditionally seen as being characterised by high labour and low technology intensity, and products whose life cycle is rather short. They are further characterised by high demand elasticity and a high structural fragmentation in the market. Companies in the CPG sector - which boasts a long tradition in marketing and communication policies and approaches aimed at listening to customers in a continuous and structured manner - are in and intermediate position, characterised by a strategic opening towards customers, however based on more traditional tools, such as Suggestions channels, Feedback/Customer experience channels and the more traditional Market-driven channels. Companies in the Pharmaceutical and Healthcare industry, characterised by intense R\&D activities, mainly implement the Technology-driven channel collaborative strategy, which targets a specialised public and is geared towards radical innovation. Consumer electronics and appliances and Automotive companies, which operate in industries with high technological intensity and product differentiation, appear to be the most open and advanced when it comes to experimenting collaborative strategies. In general, the managerial strategies connected to the investigated phenomenon appear to be influence by the specific product sector. The observed results seem to indicate that trust, as opposed to the simple transaction, is the discriminating factor. It depends on the degree of information asymmetry in the relationship with customers, in terms of information on products and features of production processes. Where the information asymmetry is wider, the physical relevance of the product becomes a key element in the company-customer relationship. Companies are more inclined to search for external collaboration when the requirements to meet are very complex and there is a great deal of uncertainty on the performance which can be obtained. As for the other corporate features, the following appear as positively correlated to the adoption of open approaches: larger size of the organizational structure, age (mature / old); presence on both B2B and B2C markets, rather than on the consumer market alone; presence of a CSR policy and specific references to Stakeholder engagement in the official corporate documentation, available online and linked to the CSR policy; a more advanced eCommerce strategy, which not only focuses on transactions, but takes social integration into account and offers additional tools and services; higher penetration of digital social channels; presence of the expressions Listening to the consumers; OI; Innovation; Openness in the official online corporate documentation.

The observed findings support evidence from previous contributions in the literature. For example, Brockhoff (2003) stated that collaborative innovation with consumers (CIC) relationship appears to differ by industry; Greer and Lei (2012), in their conceptual work, conclude that "the nature of industry may be a driving of a restraining force for CIC" (ivi, p. 74). Barbarito (2004), in a national study on 113 different sectors, explores the 
link between sectorial structural features and relational behaviour adopted by companies. His conclusion is that, despite the clear customisation of implemented tools, the characteristics of the sector where a company operates do influence the choices on the way in which companies relate to their customers. The obtained results also seem to validate the hypothesis formulated by Lichtenthaler (2008), who suggests that the openness of an organization grows with the growth of the emphasis placed on radical innovation. The differences in knowledge intensity would explain the variability of managerial approaches in heterogeneous sectors (Prahalad and Ramaswamy, 2000). The existence of a correlation with the presence on both B2B and B2C markets, rather than on the consumer market alone, can be traced back to what Ferrero and Savelli (2006) state, according to whom B2B contexts, by their own nature, tend to promote tighter relationships between the subjects in the production and distribution chain. The influence of the presence of a CSR policy in relation to the implementation of consumer involvement strategies confirms the reach and importance of the concept expressed by Devinney, Auger, Eckhardt and Birtchnell (2006) in a previous conceptual paper. They state that the Consumer Social Responsibility (CnSR) also includes a 'consumerism' component related to the preferences and desires of consumer segments. With reference to the issue of firm size, results seem to confirm what previous studies stated (Lichtenthaler, 2008; Prandelli et al., 2006), according to which larger firms have been observed to be more likely to engage in Open Innovation.

\subsection{Managerial Implications}

The study illustrates how the characteristics of Web spaces allow firms to explore new frontiers in value co-creation, offering insights on the practices that companies can incorporate to promote different kinds of external contributions. Findings identify different typologies, based on peculiar features. Managers must be aware of how relevant each may be in their strategy, understanding the firm's openness to the competence-based approach. The various modalities work in synergy, and can therefore be employed simultaneously as part of an integrated strategy. Firms should integrate these and other possible modalities to create a portfolio that they may use to for different purposes.

The contribution has also enabled the identification of emergent trends and has caught the scope of the potential of the open approach in all its nuances, different implementation modalities and objectives:

- at a more basic level of brand engagement and word of mouth;

- in order to explore the consumer day-to-day life from a closer perspective and with lower costs in comparison to off-line methods;

- with the aim of adsorbing heterogeneous inputs, even through the involvement of potential consumers who are far removed from the company's core competences;

- in order to catch interesting opportunities in terms of new knowledge generation, above all through the relational dimension that develops in Idea Communities and which influences, in a positive way, the cognitive processes.

The contribution also allows noticing that real connection is a two-way process. Particularly, managers need to acknowledge that true customer centricity can only come when they facilitate this approach: consumers own resources which can be effectively mobilised through the transformation of market connections into authentic communicative relations.

The study also has implications for research on OI. It draws attention to problems in terms of time, resources, skills and planning needed to deal with the flow of external ideas and suggestions, of potentially unlimited quantity, highly variable quality and presenting intellectual property ownership issues.

Finally, another important aspect that the study highlights concerns the mutual gains and rewards in collaborative processes. It draws attention to the balance of mutual benefits: to this end, managers should ensure that both parties perceive that they are gaining the same advantages, thus stimulating and encouraging the consumer to take part in the relationship.

\subsection{Limitations and Directions for Future Research}

This study presents a recent multi-factorial investigation of the topic where literature lacks in, but limitations about the analysis carried out should be also considered. First, findings are limited by the fast-paced nature of the Internet and the rapid dynamics related to virtual environments. Some practices may have changed since the data collection was conducted. Besides, the analysis is of explorative type, and therefore requires further investigation. It could be improved with a wider survey based on data coming directly from the voice of firms and management staff, including other product sectors in addition to the covered industries, for the purpose of testing the reach of 
the emerged findings. Similarly, while the survey unit of this empirical study focused on open virtual spaces, future investigations could include more selective approaches of consumer involvement beyond mass-open modalities.

In addition, data are only considered from a corporate perspective. Future research may extend this method by examining other variables linked to the micro-level, particularly to consumer audience and its responses, for example by investigating the relationship between the topic and: reputation, consumer loyalty, effectiveness of products.

\section{References}

Afuah, A. (2003). Redefining Firm Boundaries in the Face of the Internet: Are Firms Really Shrinking? Academy of Management Review, 28(1), 34-53. http://dx.doi.org/10.5465/AMR.2003.8925207

Ahuja, V., \& Medury, Y. (2010). Corporate blogs as e-CRM tools-Building consumer engagement through content management. Journal of Database Marketing and Customer Strategy Management, 17(2), 91-105. http://dx.doi.org /10.1057/dbm.2010.8

Alexy, O., Criscuolo, P., \& Salter, A. (2012). Managing Unsolicited Ideas for R\&D. California Management Review, 54(3), 116-139. http://dx.doi.org/10.1525/cmr.2012.54.3.116

Andrade, E. B., Kaltcheva, V., \& Weitz, B. (2002). Self-Disclosure on the web: The impact of privacy policy, reward and company reputation. Advances in Consumer Research, XXIX, 350-353. Retrieved from http://www.acrwebsite.org/search/view-conference-proceedings.aspx? $\mathrm{Id}=8674$

Banfield, J. D., \& Raftery, A. E. (1993). Model-based Gaussian and non-Gaussian clustering. Biometrics, 49, 803-821. http://dx.doi.org/10.2307/2532201

Barbarito, L. (2004). Economia delle relazioni. Tipologie settoriali e modalità relazionali nell'industria Italiana. Milano: FrancoAngeli.

Berthon, P. R., Campbell, C. L., Pitt, L. F., \& McCarthy, I. (2011). Creative Consumers: Awareness, Attitude and Action. Journal of Consumer Marketing, 28(7), 500-507. http://dx.doi.org/10.1108/07363761111181482

Berthon, P. R., Pitt, L. F., McCarthy, I., \& Kates, S. M. (2007). When Customers Get Clever: Managerial Approaches to Dealing with Creative Consumers. Business Horizons, 50(1), 39-48. http://dx.doi.org/10.1016/j.bushor.2006.05.005

Bilgram, V., Brem, A., \& Voigt, K. I. (2008). User-Centric Innovations in New Product Development Systematic Identification of Lead Users Harnessing Interactive and Collaborative Online-Tools. International Journal of Innovation Management, 12(3), 419-458. http://dx.doi.org/10.1142/S1363919608002096

Blattberg, R., \& Deighton, J. (1991). Interactive Marketing: Exploiting the Age of Addressability. Sloan Management Review, 33(1), 5-14. Retrieved from http://sloanreview.mit.edu/article/interactive-marketing-exploiting-the-age-of-addressability/

Boztepe, S. (2005). User-Value-Based Product Adaptation. Proceedings of the 6th International Conference of the European Academy of Design, Bremen, Germany. Retrieved from http://ead.verhaag.net/fullpapers/ead06_id166_2.pdf

Brockhoff, K. (2003). Customers' perspectives of involvement in new product development. International Journal of Technology Management, 26(5/6), 464-481. http://dx.doi.org/10.1504/IJTM.2003.003418

Brodie, R. J., Hollebeek, L. D., Jurlic, B., \& Ilic A. (2011). Customer engagement: conceptual domain, fundamental propositions, and implications for research. Journal of Service Research, 13(3), 252-271. http://dx.doi.org/10.1177/1094670511411703

Bruce, M., Leverick, F., Littler, D., \& Wilson D. (1995). Success factors for collaborative product development: a study of suppliers of information and communication technology. $R \& D$ Management, 25(1), 33-44. http://dx.doi.org/10.1111/j.1467-9310.1995.tb00898.x

Butera, F. (1995). Human oriented management of Change. A conceptual model. Advances in Human Factors/Ergonomics, 20/b, 1003-1010. http://dx.doi.org/10.1016/S0921-2647(06)80344-8

Chesbrough, H. (2003). Open Platform Innovation: Creating Value from Internal and External Innovation. Intel $\begin{array}{lllll}\text { Technology } & \text { Journal, } & \text { 5-9. } & \text { Retrieved } & \text { from }\end{array}$ 
https://noggin.intel.com/content/open-platform-innovation-creating-value-from-internal-and-external-innov ation

Chesbrough, H. (2006). Open Business Models: How to Thrive in the New Innovation Landscape. Boston: Harvard Business School Press.

Chesbrough, H. (2011). Open Services Innovation: Rethinking Your Business to Grow and Compete in a New Era. San Francisco: Jossey-Bass.

Christopher, M., Payne, A., \& Ballantyne, D. (1991). Relationship Marketing. Oxford: Butterworth-Heinemann.

Cova, B., \& Cova, V. (2012). On the road to prosumption: marketing discourse and the development of consumer competencies. Consumption Markets and Culture, 15(2), 149-168. http://dx.doi.org/10.1080/10253866.2012.654956

Dahan, E., \& Hauser, J. R. (2002). The Virtual Customer. Journal of Product Innovation Management, 19(5), 332-354. http://dx.doi.org/10.1111/1540-5885.1950332

Danneels, E. (2002). The Dynamics of Product Innovation and Firm Competences. Strategic Management Journal, 23(12), 1095-1121. http://dx.doi.org/10.1002/smj.275

Day, G. (1991). Learning about markets. Marketing Association Report, 91-117. Cambridge (MA): Marketing Science Institute. Retrieved from http:/www.msi.org/reports/learning-about-markets/

Devinney, T. M., Auger, P., Eckhardt, G., \& Birtchnell, T. (2006). The other CSR. Stanford Social Innovation Review, 4(3), 32-33; 35-37. Retrieved from http://www.ssireview.org/articles/entry/the_other_csr

Duncan, T., \& Moriarty, S. E. (1998). A communication-based marketing model for managing relationships. The Journal of Marketing, 62(2), 1-13. http://dx.doi.org/10.2307/1252157

Etgar, M. (2008). A descriptive model of the consumer co-production process. Journal of the Academy of Marketing Science, 36(1), 97-108. http://dx.doi.org/10.1007/s11747-007-0061-1

Ferrero, G., \& Savelli, E. (2006). La dinamica del rapporto User/Producer nell'innovazione di prodotto: analisi teoriche ed evidenze empiriche. In Atti del V Congresso Internazionale Le tendenze del marketing, Venezia, 20-21 gennaio 2006, Retrieved 1-16. from http://www.escp-eap.eu/conferences/marketing/2006_cp/Materiali/Paper/It/Ferrero_Savelli.pdf

Fuchs, C., \& Schreier M. (2011). Customer empowerment in new product development. Journal of Product Innovation Management, 28(1), 17-32. http://dx.doi.org/10.1111/j.1540-5885.2010.00778.x

Fuchs, C., Prandelli, E., \& Schreier, M. (2010). The Psychological Effects of Empowerment Strategies on Consumers' Product Demand. Journal of Marketing, 74(1), 65-79. http://dx.doi.org/10.1509/jmkg.74.1.65

Füller, J. (2010). Refining Virtual Co-Creation from a Consumer Perspective. California Management Review, 52(2), 98-122. http://dx.doi.org/10.1525/cmr.2010.52.2.98

Füller, J., \& von Hippel, E. (2008). Costless Creation of Strong Brands by User Communities: Implications for Producer-Owned Brands. MIT Sloan School of Management Working Paper, 4718-08: 1-30. http://dx.doi.org/10.2139/ssrn.1275838

Füller, J., Jawecki, G., \& Muhlbacher, H. (2007). Innovation creation by online basketball communities. Journal of Business Research, 60, 60-71. http://dx.doi.org/10.1016/j.jbusres.2006.09.019

Füller, J., Muhlbacher, H., Matzler, K., \& Jawecki G. (2009). Consumer empowerment through internet-based co-creation. Journal of Management Information Systems, 26, 71-102. http://dx.doi.org/10.2753/MIS0742-1222260303

Gales, L., \& Mansour-Cole, D. (1995). User involvement in innovation projects: Toward a theory of user information processing. Journal of Engineering and Technology Management, 12, 77-109. http://dx.doi.org/10.1016/0923-4748(95)00005-7

Gambetti, R. C., \& Graffigna, G. (2010). The concept of engagement: A systematic analysis of the ongoing marketing debate. International Journal of Market Research, 52(6), 801-826. http://dx.doi.org/10.2501/S147078531020166

Garcia Martinez, M. (2013). Open Innovation in the Food and Beverage Industry. Cambridge, UK: Woodhead Publishing. 
Gergen, K. J., Gergen, M. M., \& Barrett, F. J. (2004). Dialogue: Life and Death of the Organization, in Handbook of Organizational Discourse. CA: Sage.

Golinelli, G. M. (2010). Viable Systems Approach (VSA). Governing Business Dynamic. Padova, IT: Cedam, Kluwer.

Granat, P. (2006). Strategy first: How to make Web 2.0 work for you. Public Relations Tactics, 13(11), 38-38.

Greer, C. R., \& Lei, D. (2012). Collaborative Innovation with Customers: A Review of the Literature and Suggestions for Future Research. International Journal of Management Reviews, 14, 63-84. http://dx.doi.org/10.1111/j.1468-2370.2011.00310.x.

Grönross, C. (1990). Relationship Approach to Marketing in Service Contexts: The Marketing and Organizational Behavior Interface. Journal of Business Research, 20(1), 3-11. http://dx.doi.org/10.1016/0148-2963(90)90037-E

Gummesson, E. (2002). Relationship marketing in the new economy. Journal of Relationship Marketing, 1(1), 37-57. http://dx.doi.org/10.1300/J366v01n01_04

Hatch, M. J., \& Schultz, M. (2010). Toward a theory of brand co-creation with implications for brand governance. The Journal of Brand Management, 17, 590-604. http://dx.doi.org/10.1057/bm.2010.14

Hoeffler, S., \& Keller, K. L. (2002). Building Brand Equity through Corporate Societal Marketing. Journal of Public Policy and Marketing, 21(1), 78-89. http://dx.doi.org/10.1509/jppm.21.1.78.17600

Jespersen, K. R. (2011). Online Channels and Innovation: Are Users being Empowered and Involved? Journal of Innovation Management, 15(6), 1141-1159. http://dx.doi.org/10.1142/S1363919611003684

Kaiser, S., \& Müller-Seitz, G. (2008). Leveraging lead user knowledge in software development. The case of weblog technology economics of open-source collaboration. Industry and Innovation, 15(2), 199-221. http://dx.doi.org/10.1080/13662710801954542

Kaplan, A. M., \& Haenlein, M. (2009). The fairyland of Second Life: Virtual social worlds and how to use them. Business Horizons, 52(6), 563-572. http://dx.doi.org/10.1016/j.bushor.2009.07.002

Kaplan, A. M., \& Haenlein, M. (2010). Users of the world, unite! The challenges and opportunities of Social Media. Business Horizons, 53(1), 59-68. http://dx.doi.org/10.1016/j.bushor.2009.09.003

Kärkkäinen, H., Jussila, J., \& Väisänen, J. (2013). Social Media Use and Potential in Business-to-Business Companies' Innovation. International Journal of Ambient Computing and Intelligence (IJACI), 5(1), 53-71. http://dx.doi.org/10.4018/jaci.2013010104

Kassarjian, H. H. (1977). Content analysis in consumer research. Journal of consumer research, 4, 8-18. http://dx.doi.org/10.1086/208674

Keinz, P., Hienerth, C., \& Lettl, C. (2012). Designing the Organization for User-driven Innovation. Journal of Organization Design, 1(3), 20-36. http://dx.doi.org/10.7146/jod.1.3

Kim, J. H., Bae, Z., \& Kang, S. H. (2008). The role of online brand communities in new product development: case studies on digital product manufacturers in Korea. International Journal of Innovation Management, 12, 357-376. http://dx.doi.org/10.1142/S1363919608002011

Korkman, O., Storbacka, K., \& Harald, B. (2010). Practices as markets: Value co-creation in e-invoicing. Australasian Marketing Journal, 18(4), 236-247. http://dx.doi.org/10.1016/j.ausmj.2010.07.006

Krippendorff, K. (1980). Content Analysis: An Introduction to its Methodology. London: Sage.

Krishnan, V., \& Ulrich, K. T. (2001). Product development decisions: A review of the literature. Management Science, 47(1), 1-21. http://dx.doi.org/10.1287/mnsc.47.1.1.10668

Lane, D. A., \& Maxfield, R. (2005). Ontological Uncertainty and Innovation. Journal of Evolutionary Economics, 15(1), 3-50.

Lane, D. A., Serra, R., Villani, M., \& Ansaloni, L. (2006). A Theory-Based Dynamical Model of Innovation Processes. ComplexUs, 2, 177-194. http://dx.doi.org/10.1159/000093689

Lavrakas, P. J. (2008). Encyclopedia of survey research methods. Thousand Oaks, CA: Sage Publication Inc.

Lichtenthaler, U. (2008). Open innovation in practice: an analysis of strategic approaches to technology transactions. IEEE Transactions on Engineering Management, 55(1), 148-157. http://dx.doi.org/10.1109/TEM.2007.912932 
Magnusson, P. R. (2009). Exploring the Contributions of Involving Ordinary Users in Ideation of Technology-Based Services. Journal of Product Innovation Management, 26(5), 578-593. http://dx.doi.org/10.1111/j.1540-5885.2009.00684.x

McKenna, R. (1991). Relationship Marketing: Successful Strategies for the Age of the Customer. Cambridge, MA: Perseus Publishing.

Morgan, J., \& Wang, R. (2010). Tournament for Ideas. California Management Review, 52(2), 77-97. http://dx.doi.org/10.1525/cmr.2010.52.2.77

Nambisan, S. (2002). Designing virtual customer environments for new product development: toward a theory. Academy of Management Review, 27(3), 392-413. http://dx.doi.org/10.5465/AMR.2002.7389914

Nambisan, S. (2003). Information Systems as a Reference Discipline for New Product Development. MIS Quarterly, 27(1), 1-18. http://misq.org/information-systems-as-a-reference-discipline-for-new-product-development.html

Nambisan, S., \& Baron, R. A. (2007). Interactions in virtual customer environments: Implications for product support and customer relationship management. Journal of Interactive Marketing, 21(2), 42-62. http://dx.doi.org/10.1002/dir.20077

Nambisan, S., \& Baron, R. A. (2009). Virtual customer environments: Testing a model of voluntary participation in value co-creation activities. The Journal of Product Innovation Management, 26(4), 388-406. http://dx.doi.org/10.1111/j.1540-5885.2009.00667.x

Nambisan, S., \& Sawhney, M. (2007). The global brain: Your Roadmap for Innovating Faster and Smarter in a Networked World. Wharton School Publishing, PA.

Nonaka, I. (1991). The knowledge-creating company. Harvard Business Review, 69(6), 96-104. http:/hbr.org/1991/11/the-knowledge-creating-company/ar/1

Nonaka, I., \& Takeuchi, H. (1996). The knowledge-creating company: How Japanese companies create the $\begin{array}{lllll}\text { dynamics of innovation. Long Range Planning, } & \text { 29(4), }\end{array}$ http://dx.doi.org/10.1016/0024-6301(96)81509-3

Ojanen, V., \& Hallikas, J. (2009). Inter-organisational routines and transformation of customer relationships in collaborative innovation. International Journal of Technology Management, 45(3/4), 306-322. http://dx.doi.org/10.1504/IJTM.2009.022655

Orlikowski, W. J. (2000). Using technology and constituting structures: A practice lens for studying technology in organizations. Organization science, 11(4), 404-428. http://dx.doi.org/10.1287/orsc.11.4.404.14600

Page, K. L., \& Pitt, L. (2011). Web 2.0, Social Media, and Creative Consumers: Special Issue. Journal of Consumer Behaviour, 10(6), 313-372. http://dx.doi.org/10.1002/cb.390

Palmer, I., Benveniste, J., \& Dunford, R. (2007). New organizational forms: towards a generative dialogue. Organization Studies, 28, 12: 1829-1847. http://dx.doi.org/10.1177/0170840607079531

Payne, A. F., Storbacka, K., \& Frow, P. (2008). Managing the co-creation of value. Journal of the Academy of Marketing Science, 36(1), 83-96. http://dx.doi.org/10.1007/s11747-007-0070-0

Pepper, D., \& Rogers, M. (1993). The One-to-One Future: Building Relationships One Customer at a Time. New York, NY: Currency/Doubleday.

Perks, M., \& Sedley, R. (2008). Winners and Losers in a Troubled Economy: How to Engage Customers Online to Gain Competitive Advantage. cScape Strategic Internet Services Ltd.

Prahalad, C. K., \& Ramaswamy, V. (2000). Co-opting customer competence. Harvard Business Review, 78(1), 79-87. http://hbr.org/2000/01/co-opting-customer-competence/ar/1

Prahalad, C. K., \& Ramaswamy, V. (2004a). Co-creation Experiences: The Next Practice in Value Creation. Journal of Interactive Marketing, 18(3), 5-14. http://dx.doi.org/10.1002/dir.20015

Prahalad, C. K., \& Ramaswamy, V. (2004b). Co-creating unique value with the customers. Strategy and Leadership, 32(3), 4-9. http://dx.doi.org/10.1108/10878570410699249

Prahalad, C. K., \& Ramaswamy, V. (2004c). The Future of Competition: Co-creating Unique Value with Customers. Boston, MA: Harvard Business School Press. 
Prandelli, E., Sawhney, M., \& Verona, G. (2008). Collaborating with Customers to Innovate. Conceiving and Marketing Products in the Network Age. Edgar, Sheffield Brightman.

Prandelli, E., Verona, G., \& Raccagni, D. (2006). Diffusion of Web-based product innovation. California Management Review, 48(4), 109-135. http://dx.doi.org/10.2307/41166363

Ramirez, R. (1999). Value co-production: intellectual origins and implications for practice and research. Strategic Management Journal, $20(1)$, 49-65. http://dx.doi.org/10.1002/(SICI)1097-0266(199901)20:1<49::AID-SMJ20>3.0.CO;2-2

Romero, D., \& Molina, A. (2011). Collaborative networked organisations and customer communities: value co-creation and co-innovation in the networking era. Production Planning and Control: The Management of Operations, 22(5-6), 447-472. http://dx.doi.org/10.1080/09537287.2010.536619

Russo-Spena, T., \& Mele, C. (2012). "Five Co-s" in innovating: a practice-based view. Journal of Service Management, 23(4), 527-553. http://dx.doi.org/10.1108/09564231211260404

Sawhney, M., Verona, G., \& Prandelli, E. (2005). Collaborating to Create: The Internet as a Platform for Customer Engagement in Product Innovation. Journal of Interactive Marketing, 19(4), 4-17. http://dx.doi.org/10.1002/dir.20046

Senge, P. M., Kleiner, A., Roberts, R., Ross, R., Roth, G., \& Smith, B. (1994). The Fifth Discipline Fieldbook: Strategies and Tools for Building a Learning Organization. New York: Doubleday.

Shaw, D., Newholm, T., \& Dickinson, R. (2006). Consumption as voting: an exploration of consumer empowerment. European Journal of Marketing, 40(9/10), 1049-1067. http://dx.doi.org/10.1108/03090560610681005

Slater, S. F., \& Narver, J. C. (1998). Customer-led and market-oriented: let's not confuse the two. Strategic Management Journal, 19(10), 1001-1006. http://dx.doi.org/10.1002/(SICI)1097-0266(199810)19:10\%3C1001::AID-SMJ996\%3E3.0.CO;2-4

Stavrakantonakis, I., Gagiu, A-E., Toma, I., \& Fensel, D. (2013). Towards Online Engagement via the Social Web. Proceedings of the 1st International Conference on Building and Exploring Web Based Environments (WEB2013). Seville, Spain, January 27, 2013 - February 1, 2013. Retrieved from http://www.thinkmind.org/download.php?articleid=web_2013_2_20_40055

Stokes, D. (2000). Entrepreneurial marketing: a conceptualisation from qualitative research. Qualitative Market Research: An International Journal, 3(1), 47-54. http://dx.doi.org/10.1108/13522750010310497

Swink, M. (2006). Building Collaborative Innovation Capability. Research Technology Management, 49(2), 37-47. http://www.ingentaconnect.com/content/iri/rtm/2006/00000049/00000002/art00006

Thomke, S. (1998). Managing Experimentation in the Design of New Products. Management Science, 44(6), 743-762. http://dx.doi.org/10.1287/mnsc.44.6.743

Thomke, S., \& von Hippel, E. (2002). Customers as Innovators: A New Way to Create Value. Harvard Business Review, 80(4), 74-81. http://hbr.org/2002/04/customers-as-innovators-a-new-way-to-create-value/ar/1

Urban, G. L., \& Hauser, J. R. (2002). Listening in to find unmet customer needs and solutions. Working Paper, 156, July, Center for eBusiness, Mit Press. http://dx.doi.org/10.2139/ssrn.373061

Vargo, S. L. (2009). Toward a Transcending Conceptualization of Relationship: a Service-Dominant Logic Perspective. Journal of Business and Industry Marketing, 24(5/6), 373-379. http://dx.doi.org/10.1108/08858620910966255

Vargo, S., \& Lusch, R. F. (2004). Evolving to a New Dominant Logic for Marketing. Journal of Marketing, 68, 1-17. http://dx.doi.org/10.1509/jmkg.68.1.1.24036

Vargo, S., \& Lusch, R. F. (2006). The Service Dominant Logic of Marketing. Dialog, Debate and Directions. Armonk, New York: M.E. Sharpe.

Vargo, S., \& Lusch, R. F. (2008). Service-dominant logic: continuing the evolution. Journal of the Academic Marketing $\quad$ Science, $\quad 36, \quad 1-10 . \quad$ Retrieved from http://www.sdlogic.net/Vargo_and_Lusch_2008_JAMS_Continuing.pdf

Vasalou, A., Joinson, A., Bänziger, T., Goldie, P., \& Pitt, J. (2008). Avatars in social media: Balancing accuracy, playfulness and embodied messages. International Journal of Human-Computer Studies, 66(11), 801-811. http://dx.doi.org/10.1016/j.ijhcs.2008.08.002 
Verona, G. (1999). A Resource-based View of Product Development. Academy of Management Review, 24(1), 132-142. http://dx.doi.org/10.5465/AMR.1999.1580445

Vivek, S. D., Beatty, S. E., \& Morgan, R. M. (2012). Consumer engagement: Exploring customer relationships beyond purchase. Journal of Marketing Theory and Practice, 20(2), 122-146. http://dx.doi.org/10.2753/MTP1069-6679200201

von Hippel, E. (1976). The Dominant Role of Users in the Scientific Instrument Innovation Process. Research Policy, 5(3), 212-239. http://dx.doi.org/10.1016/0048-7333(76)90028-7

von Hippel, E. (1978). Successfull Industrial Products From Customer Ideas. Journal of Marketing, 42, 39-49. Retrieved from http://evhippel.files.wordpress.com/2013/08/cap-map-1978-jour-of-mktg-evh.pdf

von Hippel, E. (1986). Lead Users: A Source of Novel Product Concepts. Management Science, 32(7), 791-805. http://dx.doi.org/10.1287/mnsc.32.7.791

von Hippel, E. (1988). The Sources of Innovation. Oxford: Oxford University Press.

von Hippel, E. (2001). Perspective: User toolkits for innovation. Journal of Product Innovation Management, 18(4), 247-257. http://dx.doi.org/10.1016/S0737-6782(01)00090-X

von Hippel, E., \& Katz, R. (2002). Shifting innovation to users via toolkits. Management Science, 48(7), 821-833. http://dx.doi.org/10.1287/mnsc.48.7.821.2817

Webster Jr, F. E. (1994). Market-Driven Management. New York: John Wiley and Sons.

Wind, J., \& Rangaswamy, A. (2001). Customerization: The Next Revolution in Mass Customization. Journal of Interactive Marketing, 15(1), 13-32. http://dx.doi.org/10.1002/1520-6653(200124)15:1<13::AID-DIR1001>3.0.CO;2-\#

Zineldin, M. (2000). Beyond relationship marketing: technologicalship marketing. Marketing Intelligence and Planning, 18(1), 9-23. http://dx.doi.org/10.1108/02634500010308549

Zwass, V. (2010). Co-Creation: Toward a Taxonomy and an Integrated Research Perspective. International Journal of Electronic Commerce, 15(1), 11-48. http://dx.doi.org/10.2753/JEC1086-4415150101

\section{Notes}

Note 1. From 2010 to 2012.

Note 2. This enables the profiling of units based on other structural characteristics in addition to the specific industry, such as company size.

Note 3. Examples of this type of strategy are represented by platforms G-WIN, General Mills; Ideas for Innovation, Campbell Soup Company; Kraft Collaboration Kitchen, Kraft Foods Group; OI Submission Portal, Unilever; Helping Your Ideas Grow, GSK; Collaborate \& Innovate, LG; Intelli-Ideas, Johnson\&Johnson, as well as dedicated pages within corporate Web sites, such as GM New Device Section, GM; Submit Your Idea, Colgate Palmolive.

Note 4. Some examples: platform IdeaWorks by The Hershey Company; simplyinnovate by Philips; the tailor made channel on the Web corporate site Chip Chat Submission by Terra Chips Brand (The Hain Celestial Group).

Note 5. Some examples: platform FordSocial Your Ideas by Ford; In the mill of my desires by Mulino Bianco Brand (Barilla Group); IdeaStorm by Dell; the Co-Creation section of the Connect + Develop new platform by P\&G; Innovation By You by Coloplast; Kellogg's Community Share an idea by Kellogg Company.

Note 6. Typical headlines of this kind of initiatives are: "Tell your story ... habits ... taste ... preferences / Show us how ... and you may win ... ".

Note 7. Examples: iDream Annual Student Challenge by Honda; Stratedge Case Study Annual Contest by GSK Consumer.

Note 8. Some examples of this are the Factory Customization by Harley-Davidson and the Barbie styled by me by Mattel.

Note 9. The main product sector in which the firm operates has been indicated; however, in some cases, this variable does not have the "mutually exclusive" feature. For Ikea, e.g., its Food Business has been considered as marginal, while Unilever operates both in the equally significant Food and Cleaning product sectors. 


\section{Appendix A}

\section{Companies in the Study}

\begin{tabular}{|c|c|c|c|c|c|}
\hline $3 M$ & Brivais Vilnis & Fiat $\operatorname{SpA}$ & JumboDiset & Pacific Brands Ltd & $\begin{array}{l}\text { STABILO } \\
\text { International GmbH }\end{array}$ \\
\hline AB Electrolux & Bruce Food Corporation & Fila Spa & Kangaro Group & Pfizer & Steelcase \\
\hline Acer Group & Bruschettini Srl & Fila USA & Kellogg Co & Philips & $\begin{array}{l}\text { Subaru Fuji Heavy } \\
\text { Industries Ltd }\end{array}$ \\
\hline Adidas Group & Calia Italia Spa & Ford Motor Company & Kimberly-Clark & Poliform SpA & Super Glue Corp \\
\hline AkzoNobel & Campbell Soup Inc. & FrieslandCampina & K-SWISS INC & Prodeco Pharma & $\begin{array}{l}\text { Svenska Cellulosa } \\
\text { Aktiebolaget SCA }\end{array}$ \\
\hline Alivar Srl & Casio & Fuyimei & $\begin{array}{l}\text { Leggett \& Platt } \\
\text { Consumer Porducts } \\
\text { Group }\end{array}$ & PSA Group & Tapizados Fama $S L$ \\
\hline American Apparel Inc & $\begin{array}{l}\text { Chiquita Brands International } \\
\text { Inc. }\end{array}$ & G. Lalo & Lego Group & Quiksilver & Tata Motors \\
\hline $\begin{array}{l}\text { Amorepacific } \\
\text { Corporation }\end{array}$ & Church \& Dwight Co. Inc & General Mills & Lenovo Group Ltd & Ravensburger & Techno Source \\
\hline AoGrand Group & Clementoni SpA & GlaxoSmithKline & LG Electronics & Reckitt Benckiser & Teflon DuPont \\
\hline Apple Inc & Colgate Palmolive & GM General Motors & Lifeway Foods Inc & Renault SA Group & $\begin{array}{l}\text { Tempur Sealy } \\
\text { International }\end{array}$ \\
\hline Artsana Group & Coloplast & Goldrooster Group & Logitech & Roche & Texas Instruments \\
\hline Asus Inc & $\begin{array}{l}\text { Columbia Sportswear } \\
\text { Company }\end{array}$ & Grünenthal Group & L'Oreal SA & Rocky Hill Loctite & The Clorox Company \\
\hline Aurora Srl & Colussi Group & Gund & $\begin{array}{l}\text { Mattel Fisher-Price } \\
\text { Inc }\end{array}$ & $\begin{array}{l}\text { Rocky Mountain } \\
\text { Chocolate Factory } \\
\text { Inc }\end{array}$ & The Hans Celestial \\
\hline aussieBum & Crocs Inc & Haba Group & Mayora Group & Room \& Board & $\begin{array}{l}\text { The Hersey Food } \\
\text { Corp }\end{array}$ \\
\hline Avery Dennison & Daiichi Sankyo & Hanesbrands Inc. & McBride plc & $\begin{array}{l}\text { Rubbermaid Home } \\
\text { Organization } \\
\text { Product \& } \\
\text { Solutions } \\
\end{array}$ & The Honest Company \\
\hline Bandai Namco & Daimler $A G$ & Harley-Davidson & Mega Brands Inc. & $\begin{array}{l}\text { Sanderson Walker } \\
\text { Greenbank Plc }\end{array}$ & Tootie Pie Co \\
\hline Barilla Group & Deli Group Co. Ltd. & Henkel Ag \& Co. & Melitta USA & Sanofi & Toshiba Corp \\
\hline Bassett Furniture & Dell Inc & Herlitz $A G$ & $\begin{array}{l}\text { MERX Furniture } \\
\text { Company }\end{array}$ & Schiapperelli SpA & Toy Vault Inc \\
\hline Bayer $A G$ & Delta Apparel & Herman Miller Inc & Micro Cars Limited & Select Harvests Ltd & Toyota Motor Corp \\
\hline Bburago & Dongbu Daewoo Electronics & Herpa & Modenas & Servier & Under Armour Inc \\
\hline $\begin{array}{l}\text { BD Becton, Dickinson } \\
\text { and Company }\end{array}$ & Eli Lilly \& Company & Holiday Kitchens & $\begin{array}{l}\text { Motorcycle Company } \\
\text { Minsk-Moto }\end{array}$ & Seven $\operatorname{SpA}$ & Unilever \\
\hline Beiersdorf & Energizer Holdings Inc & $\begin{array}{l}\text { Honda Motor } \\
\text { Company }\end{array}$ & $\begin{array}{l}\text { Motorola (Google } \\
\text { Inc) }\end{array}$ & $\begin{array}{l}\text { Silvine Sinclairs } \\
\text { Stationers }\end{array}$ & Valsoia SpA \\
\hline Bialetti Industrie SpA & Epson & Hornby Ltd & New Balance Inc & $\begin{array}{l}\text { SKECHERS USA } \\
\text { Inc }\end{array}$ & Vemedia Group \\
\hline Björn Borg AB & Ericsson & HP (Hewlett-Packard) & $\begin{array}{l}\text { New-Ray Toys } \\
\text { Company }\end{array}$ & $\begin{array}{l}\text { Smith \& Nephew } \\
\text { plc }\end{array}$ & VF Corporation \\
\hline Blistex Inc & Esselte & Hulsta & Nike Inc & Smoby Toys & Volkswagen Group \\
\hline BMW Mini & Ethan Allen Inc & Humbrol & $\begin{array}{l}\text { Ningbo Songli } \\
\text { Stationery } \\
\text { Manufacture Ltd }\end{array}$ & Société Bic & Volvo Group Corp \\
\hline bObles & Faber-Castell & $\begin{array}{l}\text { Hyundai Kia } \\
\text { Automotive Group }\end{array}$ & Nissan Motor Co Ltd & Sofa Workshop & $W D-40 C O$ \\
\hline Boots Alliance & Farmax India Ltd & $I K E A$ & Nokia Corp & SONY Corp & Wham-O \\
\hline Boss Hoss Cycles Inc & $\begin{array}{l}\text { Farook International } \\
\text { Stationery }\end{array}$ & Italeri $\operatorname{SpA}$ & $\begin{array}{l}\text { North America Kraft } \\
\text { Foods Group Inc }\end{array}$ & $\begin{array}{l}\text { Speedo } \\
\text { International Ltd }\end{array}$ & Winning Brands Corp \\
\hline Bostik Inc & Fater $\operatorname{SpA}$ & J\&J Healthcare & $P \& G$ & Spin Master LtD & Zoch Gmbh \\
\hline
\end{tabular}

\section{Copyrights}

Copyright for this article is retained by the author(s), with first publication rights granted to the journal.

This is an open-access article distributed under the terms and conditions of the Creative Commons Attribution

license (http://creativecommons.org/licenses/by/3.0/). 